\title{
LAPORAN KASUS SERIAL VARIASI TERAPI PADA KELAINAN VASKULAR
}

\author{
Sigit Wahyu Jatmiko ${ }^{1)}$, Agus Santoso Budi ${ }^{2)}$ \\ 1) Dosen Fakultas Kedokteran Universitas Islam Malang \\ 2) Staf Departemen Bedah Plastik Rekonstruksi dan Estetik Fakultas Kedokteran Universitas \\ Airlangga - RS dr.Soetomo Surabaya \\ Submitted: November 2016 | Accepted: December 2016 |Published : Januari 2017
}

\begin{abstract}
ABTRACT
Vascular anomalies will look similar, flat or raised and in various shades of blue,pink, or red. This semantic refinement was the key to a binary classification of vascular anomalies as hemangiomas or malformation. Treatment of vascular anomalies had many various modalities, by just close observation, pharmacologic therapy, chemoterapy, embolization, untill surgical excision, or combination. We described few cases of hemangiomas and arteriovenous malformations which underwent corticosteroid injection, embolisation solely or surgical excision solely or with combination of both treatment in Dr.Soetomo General Hospital Surabaya. Decision of which treatment choosed based on prior discussion between multi department involved. All of presented cases had different results and longterm follow up were still needed. (QM 2017;01:23-35)
\end{abstract}

Keyword : Vascular anomalies, classification, embolization, surgical excision

Correspondence : : papi indy@yahoo.com

\begin{abstract}
ABSTRAK
Secara klinis berbagai kelainan vaskuler memiliki kemiripan, flat atau noduler dengan variasi bentuk, variasi warna darikebiruan, pinkish sampai kemerahan. Pemeriksaan yang teliti dapat menjadi kunci utama untuk membedakan anomali vaskuler, hemangioma atau malformasi.Terapi anomali vaskuler memiliki banyak modalitas, mulai dari hanya observasi / konservatif, farmakoterapi, kemoterapi,injeksi corticosteroid, embolisasi, eksisi sampai dengan terapi kombinasi antara embolisasi dan eksisi. Kami melaporkan perbandingan terapi dari beberapa kasushemangiomadan arteriovenous malformations (AVM), yang diterapi dengan injeksi corticosteroid, embolisasi, pada kasus yang lain dilakukan eksisi, namun ada pula yang dilakukan kombinasi keduanya serta satu kasus yang hanya dilakukan observasi. Pengambilan keputusan untuk dilakukan terapi tersebut berdasarkan hasil diskusi beberapa departemen terkait.Semuanya memiliki hasil akhir yang berbeda dan tetap diperlukan follow up terhadap pasien-pasien tersebut. (QM 2017;01:23-35)
\end{abstract}

Kata kunci : anomali vaskuler,klasifikasi, embolisasi, eksisi.

Korespondensi : : papi indy@yahoo.com 


\section{PENDAHULUAN}

Anomali vaskuler seringkali sulit dibedakan secara klinis. Hal ini menyebabkan misdiagnosis yang berakibat pada tata laksana yang kurang tepat. Klasifikasi dari anomali vaskuler bawaan ada 2 grup yang berbeda, yaitu :

1. Hemangioma

2. Vascular Malformasi /non hemangioma

Secara terminologi hemangioma adalah suatumassa yang terus tumbuh dengan hiperplasia endotel selama fase proliferasi kemudian mengalami fase resolusi . Pada fase proliferasi, hemangioma berhubungan dengan peningkatan thymidine dan sel mast. Sedangkan vascular malformation (dalam hal ini adalah AVM) merupakan lesi yang secara seluler tidak dinamis. $70 \%$ dari congenital AVMs, tidak hanya mengandung hubungan mikro dan makro fistula namun juga lesi yang hemangiomatous (Rosen 2004). Szilagyi dkk, membagi stadium perkembangan sistem vaskuler, yaitu capillary network phase (pembentukan jaringan kapiler), retiform stage, dan gross differentiation phase.

Hemangioma bukan malformasi namun suatu tumor jinak dari pembuluh darah. Tumor tersebut merupakan kelainan bawaan lahir atau dapat timbul pada usia muda. Hemangioma terjadi pada capillary network stage.Fenotipnya berupa tumor yang single atau multiple pada kulit yang disebut the classic "strawberry birthmark" maupun pada lokasi tubuh yang lain.60\% terjadi pada area kepala leher, dan $70 \%$ mengalami regresi spontan .Rasio penderita laki-laki dibanding wanita adalah 1:3 (Thorne, $\mathrm{CH}$. Beasley, RW. 2007).

Arteriovenous malformations (AVM) sebenarnya dapat bermanifestasi sejak lahir dan pada umumnya membesar bersamaan dengan pertumbuhan fisik individu. Episentrum AVM disebut nidus, terdiri dari arterial feeders, fistel arteri- vena mikro dan makro serta vena-vena yang mengalami ektasis. AVM mirip dengan hemangioma atau port-wine stain. Trauma dan pubertas dapat menjadi pencetus ekspansi. Kulit dapat menjadi kemerahanatau violaceous color, suatu massa yang seakan berasal dari pembuluh darah, teraba hangat, terdapat thrill dan bruit.

Intra kranial merupakan lokasi tersering, diikuti ekstrimitas, dan organ dalam. Meskipun tidak pernah dapat berinvolusi secara spontan, terkadang AVM tidak memberikan gejala( Robert rosen dkk). Dimanapun letak AVM, kadangkala dapat menyebabkan perubahan klinis yang patologis berupa iskemia, ulserasi, nyeri intractable, dan perdarahan yang intermiten. Pada ekstrimitas bawah sering terjadi violaceous plaque. Peningkatan cardiac output dapat terjadi pada AVM di pelvis maupun ekstrimitas (Thorne, CH. Beasley, RW. 2007).

Stadium AVM dapat dilihat dari sistem clinical staging oleh Schobinger, yaitu :

- Stadium I (Quiescence) : warna merah muda kebiruan, teraba hangat, AV shunting dari continous Doppler atau 20-MHz color Doppler 
- Stadium II (Expansion): Sama dengan stadium I, namun telah ada pembesaran, pulsasi, thrill dan bruit serta tottuous/tense veins

- Stadium III (Destruction): Sama dengan diatas ditambah adanya dystrophic changes, ulserasi, perdarahan dan nyeri menetap serta ekspansi dan destruksi

- Stadium IV (Decompensation): Sama dengan stadium II ditambah gagal jantung.

Karena AVM tumbuh lambat maka tidak perlu tergesa-gesa melakukan terapi yang agresif tanpa adanya analisa yang teliti mengenai keuntungan dan resiko terapi yang akan dilakukan. Catatan output arteri dari Pulsed Doppler (dibandingkan dengan sisi normal) dapat berguna untuk memantau progresivitas AVM. MRI adalah cara terbaik untuk menegakkan diagnosa. Super selective angiography dianggap perlu jika akan dilakukan intervensi lebih jauh. (Rosen, RJ. Maldonado 2004)

\section{LAPORAN KASUS 1}

Seorang anak perempuan 1 tahun 10 bulan dibawa berobat oleh kedua orangtuanya ke poli bedah plastik RSUD Dr. Soetomo Surabaya dengan benjolan pada bibir atas kiri sejak lahir. Mula-mula muncul sebagai bercak kebiruan yang tidak menonjol, kompresible, bertambah besar tanpa ada rasa nyeri. Sejak usia 6 bulan bercak kebiruan mulai menonjol dan bertambah besar. Riwayat perdarahan pada benjolan sebanyak 4 kali terjadi oleh karena adanya trauma (terbentur). Perdarahan berhenti setelah dikompres es selama beberapa menit.Penderita belum pernah dilakukan intervensi terapi apapun. Tidak ada riwayat keluarga yang menderita penyakit serupa. Pada pemeriksaan fisik ditemukan adanya masa merah kebiruan di bibir atas kiri ukuran $4 \mathrm{x} 2 \mathrm{x}$ $2 \mathrm{~cm}$, merah kebiruan, bruit dan thrill tidak didapatkan. (Gambar. 1)

Hasil pemeriksaan darah menunjukkan kadar $\mathrm{Hb}$ 11,9gr/dl; Lekosit 8400 /uL; Trombo 190000 /uL; BUN/SK 12/0,37 mg/dl;

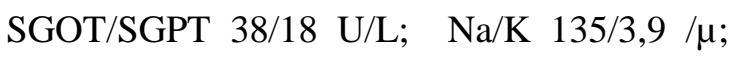
gol.drh B. Hasil foto toraks dalam batas normal. Penderita kemudian didiagnosa sebagai hemangioma labialis superior sinistra.

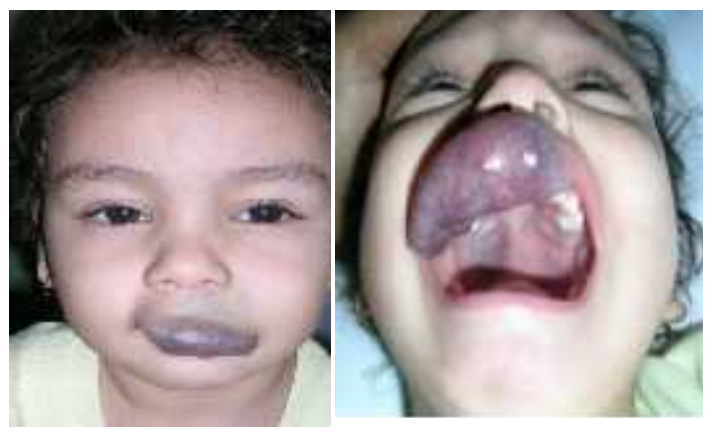

Gambar 1. Anak perempuan 1 tahun 10 bulan dengan hemangioma berupa massa yang besar, merah kebiruan pada bibir kiri atas, sebelum menjalani terapi ${ }^{\text {(Jatmiko SW,2009) }}$

Pada penderita ini dilakukan arteriografi dan didapatkan bahwa hemangioma labialis kiri tersebut mendapat feeding dari a.Facialis kiri (Gambar. 2). Dengan dasar tersebut kemudian dilakukan transarterial embolisasi dengan anestesi umum ketamin. Setelah itu diberikan injeksi Kenacort A $10 \mathrm{mg}$ intraarteriil melalui microcatheter pada feeding arteri ke hemangioma diikuti 
injeksi PVA 500 micrometer sampai terjadi pembuntuan dari hemangioma. (Gambar. 3)

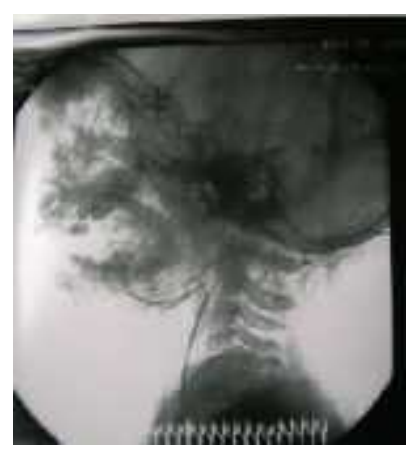

Gambar 2. Arteriografi ; hemangioma labialis kiri pada penderita mendapat feeding dari a.facialis kiri. ${ }^{\text {(Jatmiko SW,2009) }}$
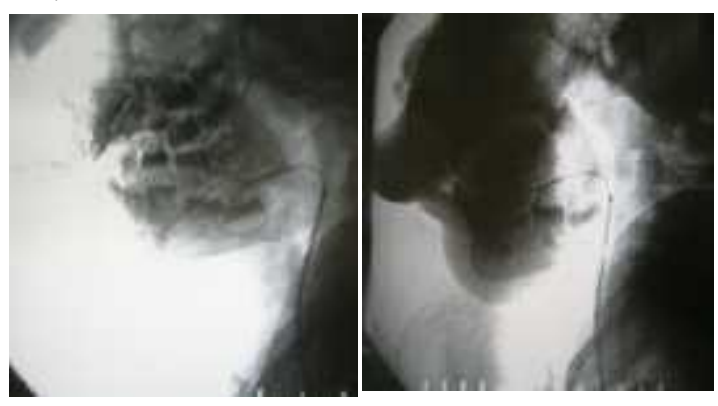

Gambar 3. Injeksi PVA 500 micrometer sampai terjadi pembuntuan dari hemangioma. ${ }^{\text {(Jatmiko SW,2009) }}$

Setelah dilakukan terapi injeksi PVA 500micrometer, pada penderita dilakukan observasi tanda-tanda vital hingga 24 jam paska tindakan (Gambar. 4 ).
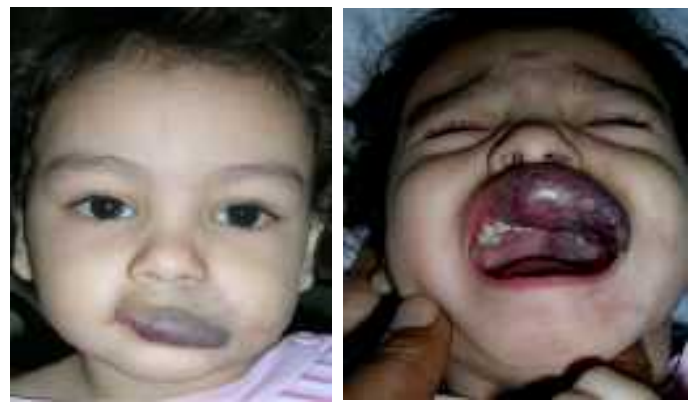

Gambar. 4. Kondisi penderita 24 jam paska tindakan ${ }^{\text {(Jatmiko SW,2009) }}$

\section{LAPORAN KASUS 2}

Seorang laki-laki 24 tahun, datang ke poliklinik RSUD Dr Soetomo Surabaya dengan keluhan utama berupa massa noduler pada daerah periorbita kiri sejak lahir. Massa yang berwarna merah keunguan ini rapuh, mudah berdarah, batas ireguler, dengan bruit. Dari riwayat terdahulu, dia mengaku telah menjalani berbagai terapi sebelumnya, seperti injeksi scleroting agent dan embolisasi, namun semuanya tidak memberikan hasil yang memuaskan. Massa tersebut bertambah besar seiring waktu makin membesar hingga menutupi matanya (Gb.5).

-Riwayat Embolisasi (I) : 21-12-2009

(kateterisasi dari a. maxillaris S, cab a.carotis ext tampak membesar dgn gambaran mass hipervaskular meluas ke daerah palpebra)

-Riwayat Embolisasi (II) : 26-01-2010

-Riwayat Embolisasi (III): a.maxillaris $\mathrm{S}$ pada feeding artery cab. Deep anterior temporal artery dan infraorbitalis artery; tidak tampak lagi kolateral pada palpaebra superior et inferior (8-3-10)

Pada pemeriksaan fisik tidak didapatkan kelainan pada status generalisnya. Status lokalis didapatkan massa regio periorbita kiri, meliputi palpebra superior dan inferior yang noduler berukuran 9x7x6 cm, biru kemerahan, permukaan ireguler, tanpa ulkus maupun perdarahan, teraba hangat, padat kenyal, tidak nyeri. Ditemukan thrill, dan bruit. Hasil pemeriksaan darah menunjukkan kadar Hb: 10,2 gr/dl; Leukosit : 10600 /uL ; Trombosit: $339000 / \mathrm{uL} \quad$; SGOT/PT : 25/31/UL ; BUN / SK : 10,9 / 1,0 mg/dl; PPT: $14,1(13,0)$; KPPT: 30,8(32,1); Na/K : $138,2 / 4,05 / \mu$. Foto toraks dalam batas normal. 
Kemudian penderita didiagnosa sebagai AVM periorbita sinistra.

Dari diskusi dengan departement bedah plastik dan radiologi diputuskan untuk dilakukan eksisi karena akan terjadi rekanalisasi apabila hanya dilakukan tindakan embolisasi saja. Dan yang menarik adalah eksisi harus dilakukan urgent maximal 1 minggu setelah dilakukan embolisasi. Akhirnya pada pasien ini eksisi dilakukan dua hari setelah dilakukan embolisasi. Hasil setelah 3 bulan terapi, kondisi luka operasi baik, tidak didapatkan tanda-tanda rekanalisasi/recurency dari AVM nya. Secara fungsional tidak ada gangguan pada penglihatan dan fungsi palpebra, secara estetika juga jauh lebih baik dari sebelumnya.
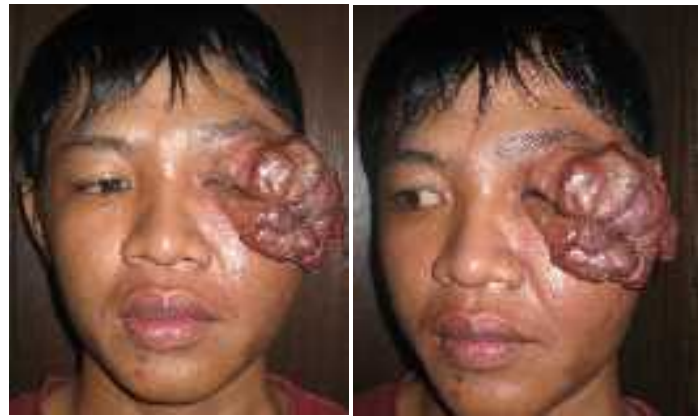

Gambar 5. kondisi setelah embolisasi kedua. (Jatmiko SW,2009)
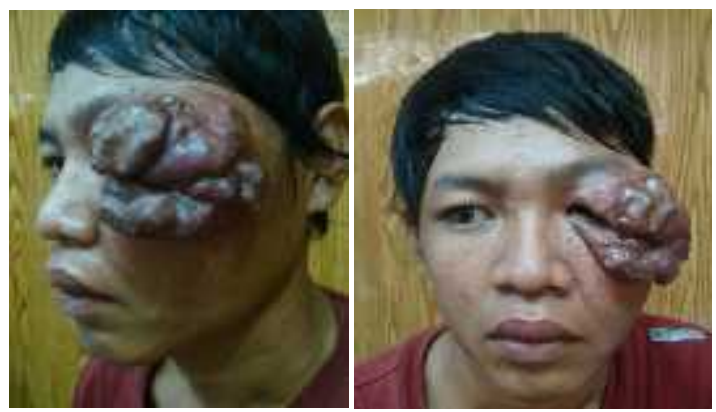

Gambar 6. Kondisi setelah embolisasi ketiga. (Jatmiko SW,2009)

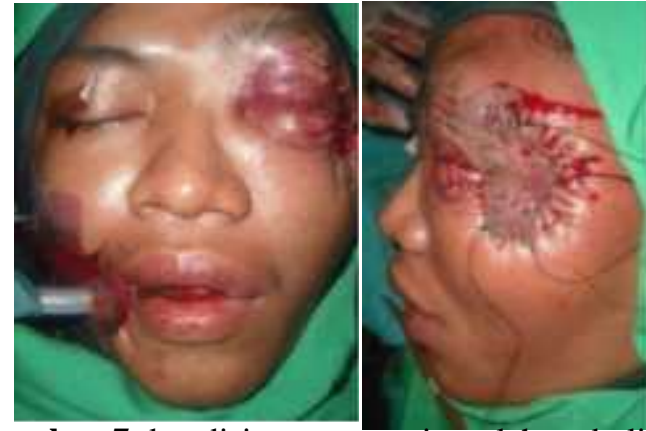

Gambar 7. kondisi post operasi setelah embolisasi ke empat. ${ }^{\text {(Jatmiko SW,2009) }}$
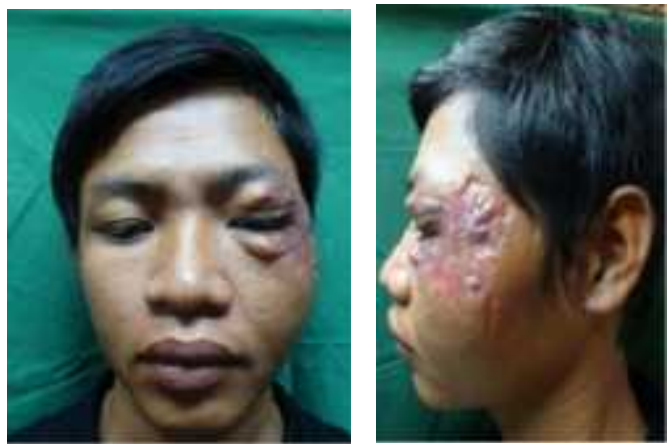

Gambar. 8. Tiga bulan setelah menjalani embolisasi dan eksisi (Jatmiko SW,2009)

\section{LAPORAN KASUS 3}

Seorang anak perempuan 6 tahun dibawa orangtuanya ke poli bedah plastik RSUD Dr Soetomo, dengan keluhan utama massa di regio fascialis sinistra sejak lahir. Penderita menjalani berbagai pemeriksaan, hingga didiagnosa sebagai hemangioma regio fasialis sinistra. Kemudian pasien menjalani pembedahan eksisi reduksi.
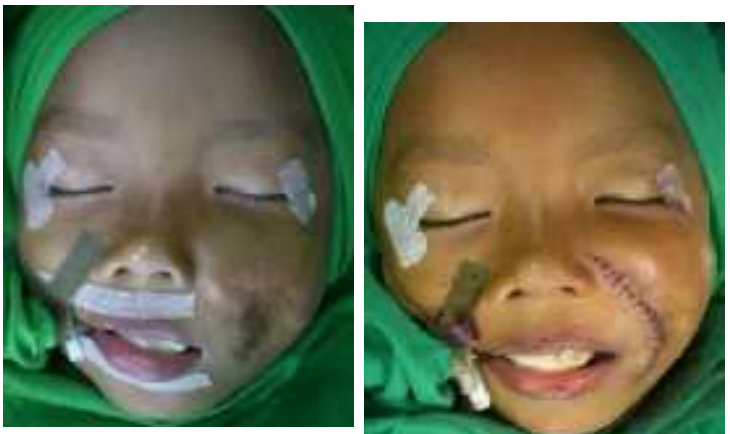

Gambar 9. Anak perempuan 6 tahun, dengan hemangioma regio fasialis sebelum dan sesudah dilakukan eksisi reduksi . (Jatmiko SW,2009) 
Hasil evaluasi 3 bulan setelah eksisi tidak didapatkan tanda-tanda rekurensi dan bekas luka (scar) juga tidak menunjukkan tandatanda penambahan massa.

\section{LAPORAN KASUS 4}

Seorang wanita usia 56 tahun, datang dengan keluhan utama massa di regio fasialis yang luas. Massa melingkupi hampir seluruh palpebral superior, sebagian hidung sisi lateral kiri dan sedikit dibawah rima orbita inferior kiri, kompresible, batas tegas, tidak didapatkan ulcerasi. Pada pasien ini seiring pertumbuhan massanya, pasien juga mengeluh mengalami gangguan saat akan membuka dan menutup mata. Penderita didiagnosa sebagai hemangioma regio fasialis, dan karena pertimbangan massa tidak dapat mengalami regresi spontan dan juga mengganggu fungsi pada saat membuka dan menutup mata, maka diputuskan untuk dilakukan terapi eksisi dengan penutupan defek menggunakan skin grafting.

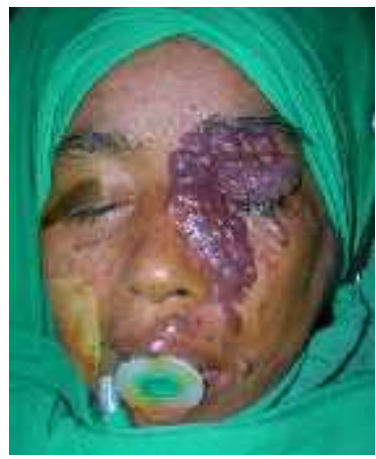

Gambar 10. Wanita 56 tahun dengan hemangioma luas regio fasialis sinistra, sebelum dan sesudah menjalani pembedahan eksisi. (Jatmiko SW,2009)
Hasil evaluasi post op setelah 3 bulan menunjukkan fungsi membuka dan menutup mata lebih baik, tidak didapatkan tanda-tanda rekurensi dan secara estetis juga jauh lebih baik dari sebelumnya.

\section{LAPORAN KASUS 5}

Seorang anak laki-laki 11 th datang bersama kedua orangtuanya ke poli bedah plastik RS Dr Soetomo Surabaya dengan keluhan utama berupa massa yang timbul sejak lahir, pada pipi sampai mulut kanan sehingga terjadi deformitas bibir, rahang atas kanan serta daerah sekitar mata kanan. Massa tersebut berwarna kebiruan dengan batas kurang tegas, kompresible, dan tidak didapatkan ulcerasi.

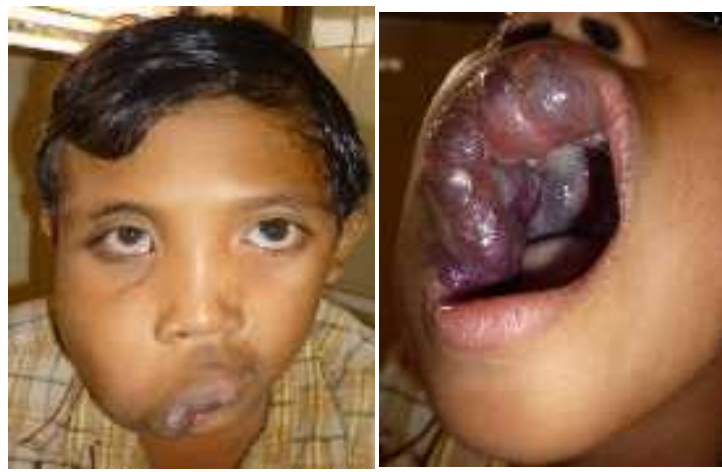

Gambar 11. Penderita sebelum dilakukan embolisasi. ${ }^{\text {(Jatmiko SW,2009) }}$

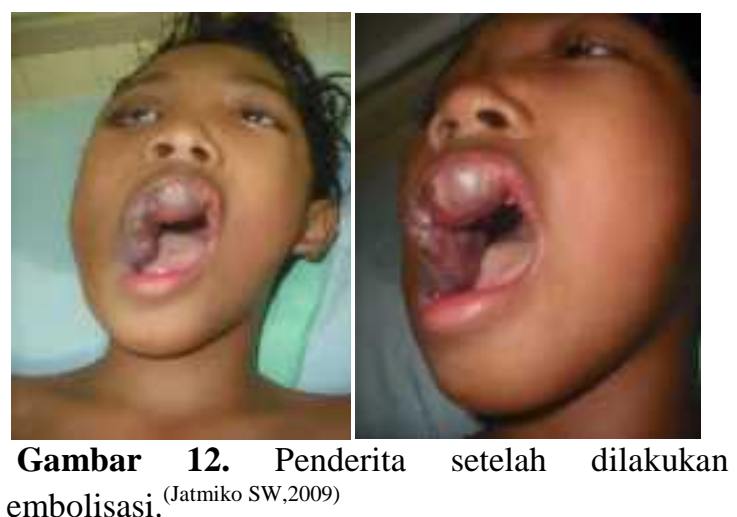
embolisasi. ${ }^{\text {(Jatmiko SW,2009) }}$ 


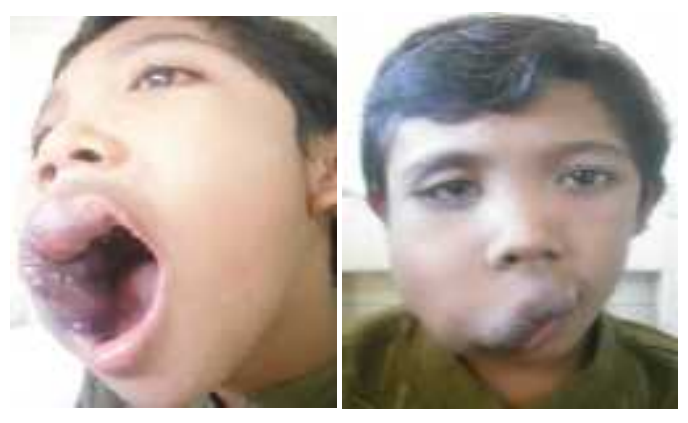

Gambar.13. Penderita sesudah 17 hari paska operasi $^{\text {(Jatmiko SW,2009) }}$

Penderita menjalani pemeriksaan arteriografi yang dilanjutkan dengan tindakan embolisasi. Evalusai hasil embolisasi pada pasien ini setelah 17 hari tindakan embolisasi tidak menunjukkan hasil yang memuaskan. Masih didapatkan massa dengan ukuran yang hampir sama dengan sebelumnya.

\section{LAPORAN KASUS 6}

Anak perempuan 11 tahun, dibawa keluarganya ke poli bedah plastik RS Dr Soetomo, Surabaya dengan benjolan pada lutut kanan. Benjolan ini timbul sejak lahir dan seiring pertumbuhannya benolan itu juga membesar walaupun perlahan.Sejak satu tahun terakhir pasien merasakan gangguan akibat dari benjolan tersebut.Dalam melakukan aktifitas sehari-hari terasa ada hambatan, kadang-kadang juga teras nyeri. Dalam pemeriksaan fisik didapatkan massa di genu kanan dengan batas tidak tegas, warna sedikit merah kebiruan, tidak nyeri, dan compressible. Pasien ini didiagnosa sebagai hemangioma regio genu kanan. Setelah dilakukan pemeriksaan penunjang, penderita menjalani eksisi.

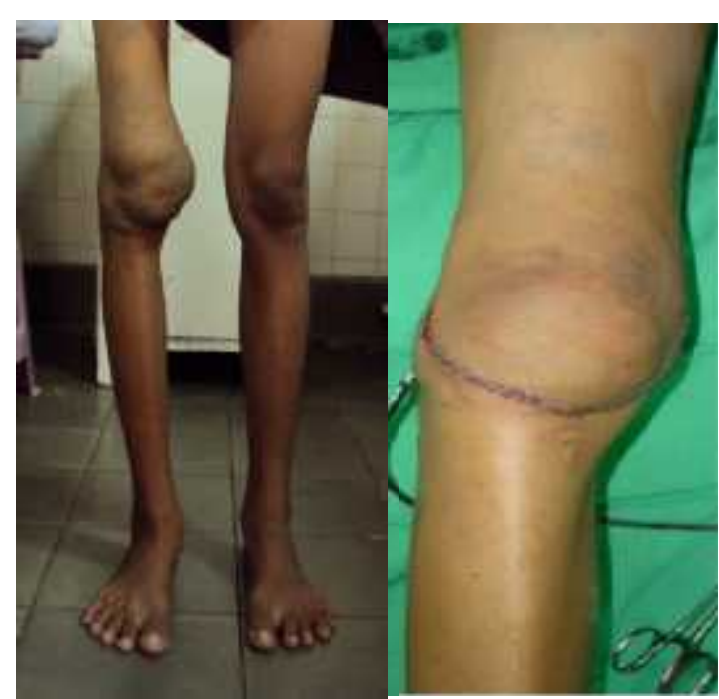

Gambar 14. kondisi pre dan post op pada hemangioma patela kanan ${ }^{\text {(Jatmiko SW,2009) }}$

Hasil evaluasi klinis setelah tiga bulan post operasi, tidak didapatkan infeksi, nyeri minimal, scar minimal, dan tidak didapatkan tanda-tanda rekurensi.

\section{LAPORAN KASUS 7}

Anak perempuan 6 tahun, dibawa keluarganya ke poli bedah plastik RS Dr Soetomo, Surabaya dengan keluhan benjolan pada pipi kiri yang dialami sejak lahir dan semakin membesar 2 tahun terakhir. Tidak pernah ada riwayat berdarah, terjadinya luka, atau tanda-tanda infeksi.Dari hasil pemeriksaan fisik didapatkan benjolan bersifat padat kenyal, kompresible, batas tegas, tidak didapatkan ulcerasi dan tanda-tanda infeksi.

Dari hasil pemeriksaan pasien kami diagnosa dengan hemangioma regio cheek kiri. Setelah dilakukan pemeriksaan penunjang, penderita kami lakukan tindakan dengan injeksi cortocisteroid intralesi.Tindakan ini kami 
lakukan di ruang operasi dengan general anastesi dengan pertimbangan lokasi pada wajah dan cukup besar serta mencegah bila anak tidak kooperatif.
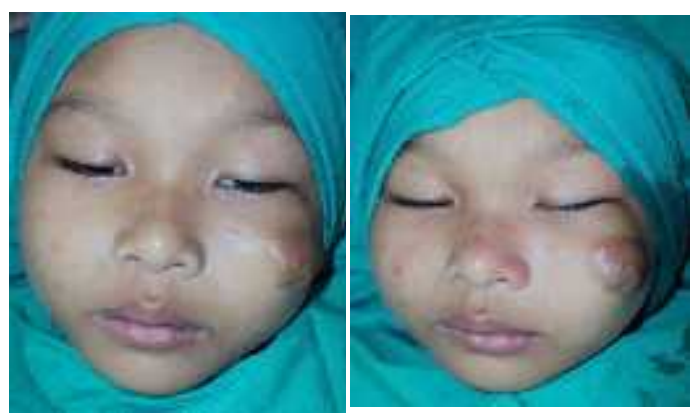

Gambar 15. Injeksi corticosteroid I. ${ }^{\text {(Jatmiko SW,2009) }}$
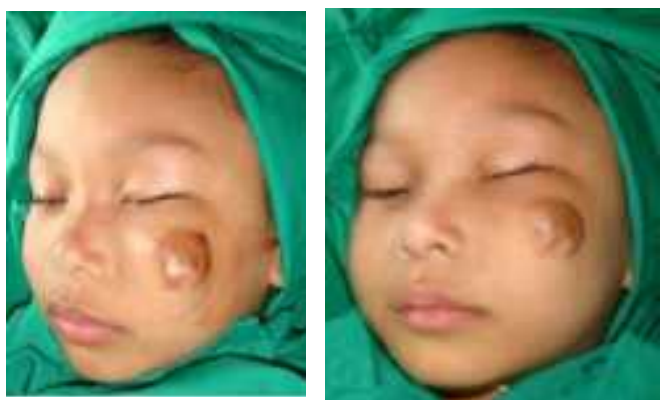

Gambar 16. Injeksi corticosteroid II (Jatmiko SW,2009)

Hasil evaluasi setelah dilakukan tindakan injeksi sebanyak tiga kali dengan rentang waktu 2 minggu kami dapatkan tidak ada tanda-tanda infeksi, ulcerasi, sedangkan ukuran massa panjang kali lebar hamper sama dengan sebelumnya dan hanya sedikit mengalami penipisan pada tebal dari massa hemangioma.Pada pasien ini masih kita rencanakan untuk penyuntikan corticosteroid lagi dengan rentang waktu 2 minggu.Namun secara umum hasil yang didapat kurang memuaskan dilihat dari parameter prosentase berkurangnya massa hemangioma.

\section{LAPORAN KASUS 8 :}

Seorang anak perempuan usia 7 tahun datang dengan keluhan ingin memperbaiki wajah sebelah kiri. Pasien ini dengan riwayat timbul bintik / benjolan kemerahan pada bibir atas kanan 10 hari sejak lahir dan makin lama makin membesar. Sejak usia 1 bulan sampai usia 1,5 tahun benjolan tersebut sering bernanah dan dilakukan perawatan sendiri dengan kompres. Pasien ini tidak pernah dioperasi, disuntik, dan tidak ada keluarga yang mengalami riwayat menderita penyakit seperti ini.

Pada usia 4 tahun kondisi luka yang sering bernanah berhenti seiring dengan mengecilnya massa dan mulai timbul bekas luka yang menimbulkan kondisi wajah sebelah kanan tidak sama dengan wajah sebelah kiri.
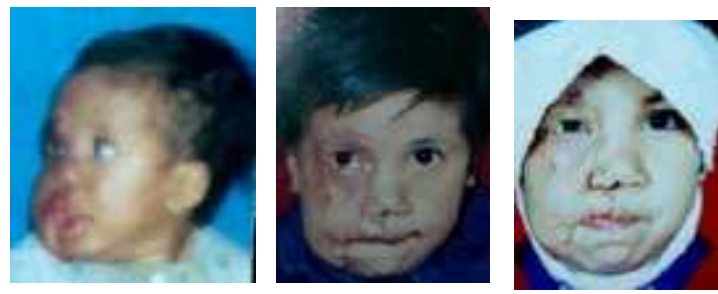

Gambar 17. Kondisi pasien dari tahun ke tahun (kanan ke kiri : usia 6 bulan, 4 tahun, 6 tahun). (Jatmiko SW,2009)

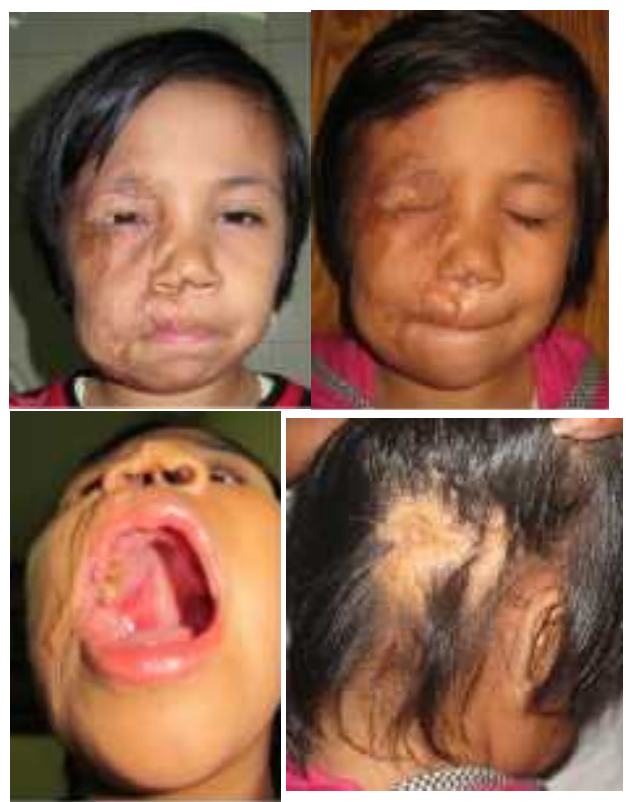

Gambar 18. Kondisi saat ini. (Jatmiko SW,2009) $^{\text {(2) }}$ 
Pasien ini kami rencanakan untuk dilakukan reconstruksi pada columela, ala nasi dan dorsum nasi, eksisi scar pada superior dari labium oris kanan

\section{DISKUSI}

Serial kasus ini membahas perbedaan mendasar pada penegakan diagnosis antara kedua jenis anomali vaskuler yaitu hemangioma dan malformasi vaskuler (AVM) serta berbagai pilihan terapi dan hasil yang dicapai. Pada diskusi ini akan dijelaskan faktor -faktor yang mendasari pengambilan keputusan untuk tatalaksana terhadap pasien yang berbeda.

\section{Hemangioma}

Hemangioma adalah tumor vaskuler yang dapat membesar karena proliferasi seluler yang cepat. Akhiran -oma menunjukkan bahwa tumot memiliki karakter suatu hiperplasia (Robbins, KV 2010) . Secara mikroskopis hemangioma menunjukkan hiperselularitas dan multiplikasi endotel. Berbeda dengan AVM yang menunjukkan selularitas endotel yang normal. 70\% kasus dapat mengalami regresi spontan, 30\% harus diterapi karena dapat mengalami deformitas.(Galiano, RD 2007)

\section{Arteriovenous malformation (AVM)}

Secara histopatologi suatu malformasi vaskuler (non neoplastik) dapat dikategorikan dalam kapiler, arteri dan vena (dengan atau tanpa fistel), dananomali limfe.Yang sering terjadi adalah kombinasi dari sub grup tersebut.

Congenital AVM berasal dari kelainan morfogenesis dari struktur vaskuler primitif dalam perkembangannya. AVM biasanya sudah timbul pada saat lahir, namun tanda dan gejalanya kadang belum tampak sampai individu tersebut dewasa. Hal ini disebabkan ukurannya yang kecil dan letaknya di organ dalam (Kenkel 2000). Pada saat pubertas dan pada masa kehamilan AVM tumbuh semakin cepat.

Secara klinis AVM memiliki tanda yang beragam. Faktor hemodinamik akibat arteri vena yang membaur secara patologis sangat mempengaruhi progresivitas AVM. Sejumlah besar darah akan mengalami shuntingke dalam pembuluh darah abnormal. Akibatnya terjadi perubahan sekunder terhadap bentuk feeding arteri dan draining vena. Arterial malformations(AM) and arteriovenous malformations (AVM) termasuk lesi - lesi high-flow, yaitu lesi yang secara hemodinamik aktif dan khas menunjukkan pulsasi, bruit, thrill dan peningkatan temperatur. Lesi ini memberat dengan meningkatnya tekanan darah, atau aliran darah dengan formasi kolateral akibat trauma. Kelompok low-flow adalahlymphatic (LM), venous (VM), dan capillary malformations (CM).

AVM bawaan dapat berlokasi dimana saja pada tubuh, yang tersering adalah ekstrimitas atas, diikuti daerah kepala leher, ekstrimitas bawah, pelvis, organ viscera. (Throut, $\mathrm{HH}$ 2005). Diagnosis AVM dapat ditegakkan dari riwayat penyakit dan pemeriksaan fisik. 
Metode non invasif seperti Doppler dan pencatatan volume pulsasi sangat berguna. Dengan angiografi, CT scan atau MRI maka ukuran feeding arteries dan ukuran shunts dapat diukur berdasarkan waktu munculnya medium kontras pada vena-vena (Nicholson 2005)

USG dapat menjadi skrining untuk menunjukkan asal vaskuler dari massa soft tissue. MRI akan menunjukkan hubungan lesi dengan struktur jaringan sekitarnya sama baiknya dengan vaskuler yang normal. Karena kelebihan itulah MRI adalah first-line diagnostic tool. Angiografi baik untuk membatu menegakkan diagnosis dan terapi pada AVM dibanding pada hemangioma. Kadang perlu dilakukan biopsi untuk meyakinkan tidak ada keganasan karena secara imaging AVM dapat menyerupai malignancy vaskuler seperti angiosarcoma dan rhabdomyosarcoma.

\section{Terapi Hemangioma dan Malformasi Vaskuler}

Tipe lesi dan lokasi yang tepat harus ditentukan dengan baik agar dapat melaksanakan terapi yang optimal dari anomali vaskuler. Beberapa lesi perlu dilakukan penanganan yang segera.

\section{Hemangioma}

Bila hemangioma tidak menyebabkan gangguan jalan nafas, penglihatan maupun gangguan visual maka yang dilakukan adalah observasional. Prosedur rekonstruksi dapat dilakukan jika involusi yang terjadi tidak sempurna atau terdapat skar yang nyata, atrofi epidermis, telangiektasis atau terjadi deposit fibro-fatty tissue.

Terapi steroid efektif hanya pada fase proliferasi saja. Pada penggunaan triamcinolon 2-5 $\mathrm{mg} / \mathrm{kg} /$ hari dalam jangka waktu 2-4 minggu, diikuti tappering of selama 8-10 minggu. Efek samping pemberian steroid yang dapat timbul berupa fenomena cushingoid, gastritis dan hiperglikemia.

Menurut teori, pulsed yellow dye laser berguna untuk hemangioma yang dini, hemangioma dengan ulserasi, dan hemangioma yang mengalami regresi namun masih mengandung pigmen vaskuler, dan yang mengalami ektasi pembuluh darah yang manifes. Terapi laser multipel dapat dilakukan setiap 2-4 minggu sampai tumor ini mengecil kemudian terjadi rebound growth. Terapi tidak perlu diteruskan lagi jika terjadi regresi permanen. Pembuluh darah yang mengalami residual ectatic dapat diberikan terapi dengan laser pulse dye untuk menghindari pembedahan. Telangiektasis yang besar juga memberikan respon yang simultan terhadap sinergisme kerja laser dan terapi sklerotik. Terapi laser tidak efektif pada hemangioma yang besar atau terletak pada lapisan sub kutan karena sinar laser tidak dapat menembus lebih dalam sehingga tidak akan memberikan perbaikan (Thorne, CH 2007).

Interferon dapat diberikan sub kutan sebagai agen untuk terapi hemangioma setiap saat dengan dosis 3x 106 unit/m2 luas tubuh/hari sampai 6-8 bulan. Tidak perlu ada tappering of. Efek samping pemberian 
interferon cukup mengganggu seperti anemia, peningkatan enzim-enzim hati, kesulitan berbicara, dan demam sampai dengan spastic diplegia yang ireversibel (Weiss 2008).

\section{Malformasi Arteri-vena (AVM)}

Penanganan AVM biasanya konservatif saja pada saat bayi atau kanak-kanak. Bila sudah ditegakkan sebagai AVM, maka anak tersebut harus diobservasi dengan baik. Embolisasi dini atau managemen pembedahan untuk stadium I dan II pada AVM masih dalam perdebatan. Bila reseksi dan rekonstruksi bisa dikerjakan, maka tidak perlu ditunda. AVM masih dapat diterapi meskipun ada tanda dan gejala seperti nyeri iskemi, ulserasi rekalsitan, perdarahan atau peningkatan cardiac output (Schobinger Stages III dan IV).Tehnik embolisasi perkutan yang dikenal ada 2, yaitu:

a.transcatheter embolization

( pada komponen arteri yang nyata)

b.direct puncture techniques

( pada vena dengan aliran lambat)

Ligasi atau embolisasi proksimal dari pembuluh darah arteri feeding tidak boleh dilakukan karena dapat menyebabkan rapid recruitment dari arteri yang menyuplai nidus. Ligasi arteri membatasi akses untuk embolisasi terapetik. Angiografi sangat membantu intervensi secara radiologis dan pembedahan. Embolisasi arteri yang selektif perupakan tindakan paliatif untuk mengurangi nyeri, perdarahan atau gagal jantung terutama jika AVM tidak dapat direseksi atau untuk menutup nidus 24-72 jam sebelum reseksi.
Komplikasi dari prosedur embolisasi terjadi bila membuntu pembuluh darah feeding terlalu proksimal atau terlalu distal, atau menutup pembuluh darah yang salah. Hal ini harus dihindari dengan pemilihan embolic agent yang sesuai. Material yang memiliki daya penetrasi tinggi seperti Gelfoam powder dapat merusak jaringan normal jika masuk dalam sirkulasi arteri yang normal. Penggunaan sistem coaxial microcatheter dan tehnik scrupulous dapat mengurangi komplikasi namun tidak menghilangkannya. Embolisasi agresif pada AVM yang besar dapat terjadi ruptur dan perdarahan akibat peningkatan aliran darah yang mendadak yang diredistribusikan ke circulation bed yang lain. Terutama pada pasien anak-anak, problem dapat meliputi vasospasme, diseksi dari arteri dan trombosis arteri.

Malformasi vena pada umumnya memerlukan sclerotherapy (intervensi dilakukan oleh spesialis radiologi) bila lesi tersbut menunjukkan gejala. Debulking surgery, jika ada indikasi baru dilakukan 6-8 minggu setelah sclerotherapy. Pada lesi dalam atau dekat struktur vital seperti tangan dan jari maka harus diterapi dengan eksisi saja.

Malformasi kapiler dapat diterapi hanya dengan laser. Lebih dari $75 \%$ memberikan hasil memuaskan. Jika lesi ini berada dibawah jaringan lunak atau hipertrofi tulang maka tetap dibutuhkan pembedahan.

\section{PEMBAHASAN}

Kedelapan penderita anomali vaskuler 
pada serial kasus diatas tidak mengalami kesulitan dalam menegakkan diagnosis. Namun disini terjadi perbedaan tata laksana berupa terapi konservatif dan pembedahan.

Pada kasus 1,2,dan 5 hemangioma pada kedua pasien ini dilakukan modalitas terapi berupa embolisasi. Namun hasil yang didapatkan kurang memuaskan dengan parameter tidak terjadi pengecilan massa yang bermakna, dan juga evaluasi yang dilakukan harus terus menerus karena untuk antisipasi kemungkinan untuk recurency masih cukup besar.

Pada kasus ke 2 : AVM pada pasien ini sebelumnya dilakukan modalitas terapi sebanyak dua kali, namun tidak didapatkan hasil yang memuaskan dengan parameter tidak teterjadinya pengecilan massa dan juga dari hasil arteriografi berikutnya menunjukan terjadi rekanalisasi dari feeding arteri yang sebelumnya telah di embolisasi.

Setelah dilakukan diskusi antara bedah plastik dengan radiologi maka diputuskan untuk dilakukan embolisasi ketiga yang dilanjutkan dengan urgent surgical eksisi dua hari setelah dilakukan embolisasi. Hasilnya cukup memuaskan dengan parameter bahwa massa yang sebelumnya semakin besar dan sangat mengganggu lapang pandang pasien dapat diambil seluruhnya, dan yang terpenting adalah evaluasi 3 bulan post operasi tidak menunjukkan tanda-tanda terjadinya rekurensi / rekanalisasi.

Pada kasus 3, 4, dan 6 :tindakan eksisi secara langsung pada kedua pasien ini memberikan hasil yang cukup memuaskan. Hal ini dapat dilihat dari sisi fungsional gangguan akibat adanya massa tersebut langsung tereduksi, tidak didapatkan rekurency. Dan secara estetik pun lebih baik.

Pada kasus ke-7 : injeksi corticosteroid pada hemangioma cheek sinistra dilakukan sebanyak tiga kali dengan selang waktu 2 minggu kurang menunjukkan hasil yang kurang bermakna. Ukuran massa cenderung tetap dan hanya tebal dari massa sedikit mengecil kurang dari $3 \mathrm{~mm}$ dengan ukuran panjang dan lebar yang tetap.

Pada kasus ke-8 : observasi pada kasus hemangioma memang merupakan salah satu modalitas terapi, namun pada kasus ini walaupun pasien telah berobat/kontrol untuk evaluasi kondisi hemangiomanya, namun komplikasi berupa infeksi atau ulcerasi sangat perlu mendapat perhatian khusus. Hal ini Nampak pada kondisi pasien saat ini yang mengalami deformitas pada beberapa sisi hemifacial kiri, alopecia, dan deformitas pada telinga kiri. Sehingga modalitas berupa observasi harusnya dibatasi dan mungkin perlu dilakukan tindakan yang lain untuk mencegah komplikasi seperti yang terjadi pada pasien ini.

\section{KESIMPULAN}

Hemangioma dan Arteriovenous Malformation memiliki perbedaan dalam penegakan diagnosa secara klinis dan juga tatalaksananya.Seringkali kita membutuhkan sarana penunjang diagnostik berupa arteriografi yang sekaligus dapat dilakukan terapeutik berupa embolisasi. 
Pada delapan kasus yang kami laporkan di atas tampak bahwa dari beberapa modalitas terapi yang dilakukan memberikan hasil yang berbeda. Hal ini dipengaruhi juga oleh jenis dari kelainan vaskulernya, lokasi, komplikasi, dan skill dokter sebagai pengambil keputusan. Observasi dan evaluasi pada tindakan hemangioma pun dapat menimbulkan hasil yang tidak baik jika hal itu tidak dilakukan dengan pemantauan yang teliti terhadap kemungkinan klinis yang akan terjadi kepada pasien. Terapi embolisasi dan injeksi costicosteroid intralesi kurang memberikan hasil yang cukup bermakna jika dilihat dari parameter secara anatomik,fungsional maupun estetik. Tindakan eksisi memberikan hasil yang baik namun pada kasus anomaly vaskuler harus dengan pertimbangan yang sangat matang, mengingat resiko akan terjadinya bleeding dan terjadinya rekanalisasi sangat besar. Terapi kombinasi antara embolisasi dan surgical eksisi urgent pada kasus di atas memberikan hasil yang paling memuaskan, dengan didahului oleh diskusi yang intensif antar departemen yang terkait kita dapat mempersiapkan dengan matang rencana kapan akan dilakukan embolisasi dan kapan rencana urgent surgical eksisi dilakukan. Proses dan hasil yang dicapai juga sangat memuaskan dengan proses operasi kasus arterivenous malformation yang berlangsung sukses , perdarahan terkontrol, dan hasil operasi yang baik dengan tidak adanya rekurensi setelah evaluasi tiga bulan post operasi.

\section{REFERENSI}

Galiano, RD., Gurtner, GC. (2007) Vascular Anomalies. In Practical Plastic Surgery. Landes Bioscience. pp. 138-144

Kenkel, J., MD. (2000) Vascular Anomalies and Lymphedema. In Selected Reading in Plastic Surgery. 9(7), pp. 13-20.

Nicholson, Glovtzsky. (2005) Embriology an Development of Vascular System. in Vascular Surgery Basic Science and Clinical Correlations 2nd ed., pp.1-14

Robbin, KV. and Cotran. (2010)

Pathologic Basis of Disease. Saunders LWW · pp.520

Rosen, RJ. And Maldonado, T. (2004) Complication of vascular surgery. Towne JB, Hollier LH.Marcel Dekker, New York 2nd ed., pp.581-588.

Throut, HH. and Eifert, S. (2005) In Vascular Surgery Basic Science and Clinical Correlations. Rodney A White, M editor. 2 ed., pp.1161-1170

Thorne, CH. and Beasley, RW. (2007) in Grabb and Smith's Plastic surgery. 6th ed, LWW 2007, pp.1016-1025

Weiss, and Enzinger. (2008) 'Benign Tumors and Tumor Like Lesion of Blood Vessels'. In Soft Tissue Tumor. Mosby Elsevier, pp. 633-63 


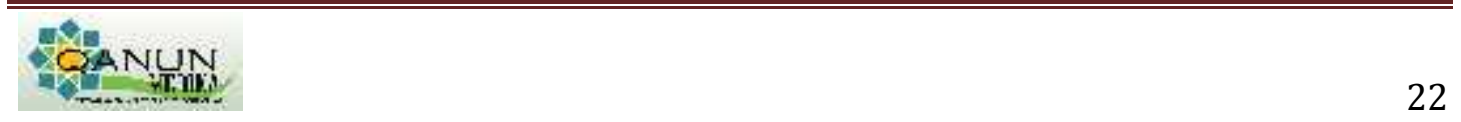

